\title{
Nobelprize 2015 for Phytomedicine
}

CrossMark

\author{
André Gessner
}

Three scientists who developed therapies isolated from natural sources against parasitic infections have won this year's Nobel Prize in Physiology or Medicine.

William C. Campbell, a microbiologist at Drew University in Madison, New Jersey and Satoshi Ōmura, a microbiologist at Kitasato University in Japan isolated avermectins from Streptomyces bacteria and tweaked the structure of one of the most promising compounds to develop it into a drug against onchocerciasis (river blindness) - ivermectin.

The second half of the nobel pize was awarded for a new plant-derived drug to Youyou $\mathrm{Tu}$, a pharmacologist at the China Academy of Chinese Medical Sciences in Beijing. Tu, who won a Lasker prize in 2011, developed the antimalarial drug artemisinin in the late 1960s and 1970s. She is the first China-based scientist to win a Nobel prize in sciences.

In the 1960s, the main treatments for malaria were chloroquine and quinine, but they were proving increasingly ineffective. Diseases caused by parasites such as malaria have been with humankind for millennia and constitute a major global health problem affecting the world's poorest populations and represent a huge barrier to improving human health and wellbeing. Malaria is a mosquito-borne disease caused by single-cell parasites infecting close to 200 million individuals yearly. The parasites invade red blood cells, causing fever, and in severe cases brain damage and death. Malaria claims more than 450000 lives, predominantly among children.

So in 1967, China established a national project against malaria to discover new therapies. Tu and her team screened more than 2,000 Chinese herbal remedies to search for drugs with antimalarial activity. An extract from the wormwood plant Artemisia annua proved especially effective and by 1972, the researchers had isolated chemically pure artemisin.

Artemisinin represents a new class of antimalarial agents that rapidly kill the Malaria parasites at an early stage of their development, which explains its unprecedented

Correspondence: andre.gessner@ukr.de

Institute of Clinical Microbiology and Hygiene, Franz-Josef-Strauss-Allee 11, Regensburg 93053, Germany potency in the treatment of severe Malaria. Nowadays, artemisinin is used in all Malaria-ridden parts of the world. When used in combination therapy, it is estimated to reduce mortality from Malaria by more than $20 \%$ overall and by more than $30 \%$ in children. For Africa alone, this means that more than 100000 lives are saved each year.

Thus, a plant-derived new drug has provided humankind with powerful new means to combat a debilitating parasitic disease that affect hundreds of millions of people annually. The consequences in terms of improved human health and reduced suffering are immeasurable.

There is increased hope that phytomedicine will deliver additional new important discoveries that transform the treatment of human diseases in the future.

Prof. Dr. Dr. André Gessner

Institute of Clinical Microbiology and Hygiene University of Regensburg

Franz-Josef-Strauss-Allee 11

D-93053 Regensburg

Received: 29 November 2015 Accepted: 29 November 2015 Published online: 03 December 2015
Submit your manuscript to a SpringerOpen ${ }^{\circ}$ journal and benefit from:

- Convenient online submission

Rigorous peer review

- Immediate publication on acceptance

- Open access: articles freely available online

- High visibility within the field

- Retaining the copyright to your article

Submit your next manuscript at $>$ springeropen.com

\section{包 Springer}

(C) 2015 Gessner. Open Access This article is distributed under the terms of the Creative Commons Attribution 4.0 International License (http://creativecommons.org/licenses/by/4.0/), which permits unrestricted use, distribution, and reproduction in any medium, provided you give appropriate credit to the original author(s) and the source, provide a link to the Creative Commons license, and indicate if changes were made. 